\title{
The Magnitude of Trade Misinvoicing and Resulting Revenue Loss in Pakistan
}

\author{
Tehseen Ahmed Qureshi* and Zafar Mahmood**
}

\begin{abstract}
This study estimates the magnitude of trade misinvoicing in Pakistan with 21 of its developed trading partners in 52 major traded commodities during 19722013. We find that the total volume of trade misinvoicing for this period exceeds US\$92.7 billion. The gross revenue loss borne by the national exchequer due to trade misinvoicing is estimated at US\$21.2 billion. Moreover, the total net revenue loss is an estimated US\$11 billion in the form of evasion of customs duties and export withholding tax. The annual average net revenue loss due to trade misinvoicing is almost equivalent to 11.2 percent of the total revenue generated from customs tariffs. We also find that customs tariffs and the interest rate are positively associated with import under-invoicing, while improvements in the current account balance and political stability reduce the extent of import overinvoicing. Capital account openness is found to be insignificant in determining trade misinvoicing.
\end{abstract}

Keywords: Trade misinvoicing, revenue loss, capital flight, reverse capital flight, black money, Pakistan.

JEL classification: F13, F14, K42, H26, O17.

\section{Introduction}

Intuitively, when two trading partners engage in trade, the data reported by one country should be the same as that reported by the other after adjusting for c.i.f./f.o.b. However, this does not happen in many cases for various reasons. Trade misinvoicing is one reason for discrepancies in bilateral trade data. Trade misinvoicing is illegal and occurs when traders under-invoice or over-invoice their exports or imports for the purposes of tax evasion or capital flight in either direction. To estimate the volume of trade misinvoicing, we compare the exports (imports) of the reporting

\footnotetext{
* PhD Scholar, Quaid-e-Azam University, Islamabad, Pakistan.

** Professor of Economics, School of Social Sciences and Humanities, National University of Science and Technology, Islamabad, Pakistan.
} 
country with the imports (exports) of the partner country after adjusting for the costs of freight and insurance.

The government loses a large amount of revenue in the form of customs duties and export taxes through trade misinvoicing. The economy is deprived of domestic capital that is transferred abroad, which could otherwise be invested domestically. This results in a decline in economic growth due to lack of capital. In addition, the loss of revenue means that the government cannot use potential resources to expand social services.

Kar and Spanjers (2015) estimate that the sum of total trade misinvoicing in 2013 in developing countries was US\$1.1 trillion. The total trade misinvoiced during 2004-13 is estimated to be around US $\$ 7.8$ trillion for 55 developing countries. Furthermore, trade misinvoicing accounts for 83 percent of the total illicit trade in developing countries. This implies that illegal financial flows resulting from trade misinvoicing have a considerable damaging impact on developing economies (Kar, 2010).

Kar and Spanjers (2015) also point out that, in the Global South, trade misinvoicing has increased over time. Trade misinvoicing in emerging countries is increasing on average at 6.5 percent per annum. The total trade misinvoiced in Asia accounts for 38.8 percent of total trade misinvoicing in emerging countries. It also has the highest annual growth rate of trade misinvoicing at 8.6 percent. The top exporters of illegal capital are Asian countries, including Malaysia, China, India, the Philippines, Indonesia and Thailand. Russia is the main source of trade misinvoicing in Europe. Illicit flows from the West are generated primarily by Mexico and Brazil.

The first study to estimate illegal flows of capital from developing countries due to trade misinvoicing was carried out by Bhagwati (1964). He compares the bilateral trade data for Turkey with that of its trading partners. He accounts for the discrepancies between the trade figures of the partner countries by indicating that either of the two or both had exploited their trade invoices to move capital. Given that the customs administration in advanced countries is more likely to be simpler, transparent and accountable relative to developing countries, we can assume that the data for developed countries is more reliable for comparison purposes (Bhagwati \& Hansen, 1973).

Historically, Pakistan has maintained very high tariff rates and relied on nontariff barriers (NTBs) to protect domestic industries from 
foreign competition. Both tariffs and NTBs are seen as major reasons for import under-invoicing. Pakistan has also offered many incentives to promote export-oriented industrialization. While these incentives have helped the country maintain a reasonable rate of export growth, many exporters have also manipulated them to their advantage by engaging in unfair and illegal practices. Such practices cause not only financial losses to the exchequer, but also undermine the very objective of these policies. Consequently, exporters who do not engage in such malpractices are subject to large losses because their bargaining position in the market tends to weaken (Mahmood \& Mahmood, 1993).

The rationale for conducting this study is to focus on those areas of trade misinvoicing in Pakistan that the literature does not address. For example, there has been no research on the issue of import over-invoicing and export under-invoicing in Pakistan with respect to commodities and trading partners. Moreover, there is little fresh research on the other two components of trade misinvoicing - import under-invoicing and export over-invoicing. The studies available date back to 1993 and 2001.

Mahmood and Mahmood (1993) and Mahmood and Azhar (2001) incorporate six and thirteen trading partners and limit their estimations to two and three years, respectively. This underestimates the actual size of trade misinvoicing. Our purpose, however, is to determine the key misinvoiced traded commodities for major trading partners with whom the largest extent of trade misinvoicing occurs. Moreover, we take into account the period since 1972 .

No other study for Pakistan estimates the revenue loss incurred through trade misinvoicing due to evasion of customs duties and withholding tax at the export stage. This study is the first to estimate the average loss in revenue due to trade misinvoicing, using the methodology applied by Baker et al. (2014). Using a simple economic framework, we develop and estimate a robust least squares model to determine which factors affect the extent of trade misinvoicing in Pakistan.

The paper is divided into six sections. Section 2 reviews the existing literature. Section 3 discusses the methodology used to estimate misinvoicing and the resulting revenue loss. The results are interpreted and discussed in Section 4. Section 5 outlines the major determinants of trade misinvoicing. Section 6 concludes the paper and draws out policy measures that could help eradicate trade misinvoicing in Pakistan. 


\section{Literature Review}

Bhagwati and Hansen's (1973) framework assumes that both legal and illicit trade are carried out at the same market price prevailing in the world. Illicit traders try to avoid tariffs and thus face a less favorable transformation rate because of the costs associated with misinvoicing. If the cost of misinvoicing is equal to the tariff rate, then both kinds of trade can coexist. However, if they are not equal, then each firm must trade legally or illicitly. Illegal trade reduces the revenues obtained from taxes without enhancing efficiency. The authors conclude that illicit trade does not have a positive impact on welfare.

De Boyrie, Nelson and Pak (2007) discuss trade misinvoicing from Africa to the US between 2000 and 2005. Their results suggest that misinvoicing has increased by around 60 percent because low export prices facilitate tax evasion and money laundering. Imports with higher prices enable capital flows and can be used to camouflage illicit commissions. The deviation from the average price of exports and imports is used as an indicator of capital outflows. Of the top 30 countries in Africa involved, four (Algeria, Tunisia, Morocco and Egypt) have moved around $\$ 6.7$ billion via trade misinvoicing. The remaining 26 have moved approximately $\$ 13.41$ billion. South Africa has moved the most capital to the US via trade misinvoicing.

Ndikumana and Boyce (2008) carry out a panel data estimation of 40 African countries to determine the magnitude of trade misinvoicing from sub-Saharan Africa during 1970-2004. They employ robust OLS, fixed effects and instrumental variables to estimate the results. The estimated value of capital flight through over-invoiced imports is $\$ 420$ million. When the imputed interest is added to this, the misinvoiced stock for these 40 countries increases to $\$ 607$ billion for 2004 .

Berger and Nitsch (2012) study the relationship between trade misinvoicing and corruption from 2002 to 2006 for the top five importers of the world: the US, Germany, China, the UK and Japan. They analyze trade statistics at the 4-digit level using the c.i.f. and f.o.b. methodology. Based on data from UN Comtrade and the IMF Direction of Trade Statistics, they find discrepancies in the figures for recorded exports by the partner countries. They conclude that trade misinvoicing by the partner countries increases with the level of corruption. 
Baker et al. (2014) study trade misinvoicing in five African countries for the period 2002 to 2011. Using UN Comtrade data, they apply Bhagwati's methodology and estimate that Tanzania experienced the highest volume of illicit flows (\$1.87 billion). Kenya follows with $\$ 1.51$ billion in average annual illicit trade flows while Ghana accounts for \$1.44 billion annually. Uganda and Mozambique rank lower with $\$ 884$ million and \$585 million in annual average illicit trade flows.

The authors also estimate the loss of revenue in the form of tariff revenues and domestic taxes for each country due to trade misinvoicing. Their results indicate that, on average per year, Ghana lost \$386 million, Kenya \$435 million, Mozambique \$187 million, Tanzania \$248 million and Uganda \$243 million during 2002-11. In each case, these losses represent resources the government was unable to capture and invest in development projects in education, infrastructure or healthcare. The opportunity foregone in providing these public goods is a symbol of the tangible harm caused by illicit financial flows in developing countries.

Fisman and Wei (2007) look at the export of cultural goods and antiques from Egypt to the US from 1996 to 2005. Using the c.i.f. and f.o.b. methodology, they find evidence of substantial illicit trade in cultural and antique goods between these countries. A key finding is that the level of export under-invoicing is highly correlated with the level of corruption in the exporting county.

Yalta and Demir (2010) survey Turkey's exports to its major trading partners to examine the extent of trade misinvoicing for the period 19702007. They find that exports are under-invoiced while imports from China are over-invoiced. They also analyze the effect of customs unions and trade liberalization policies on trade misinvoicing and conclude that liberalization policies have a negative effect on import misinvoicing at the aggregate level.

Jha and Nguyen (2014) look at India's trade with 17 major trading partners over the period 1988-2012, using Bhagwati's methodology of comparing c.i.f. and f.o.b. values after taking into account an adjustment factor of 1.1. They find that trade misinvoicing from India has increased since 2004 and peaked between 2007 and 2012. The illicit trade flow in 2008 alone was worth $\$ 40$ billion and the total illicit outflow over the 14 years exceeded $\$ 186$ billion. 
The first study to investigate import under-invoicing in Pakistan was conducted by Sheikh (1974) for the period 1965 to 1968. Using the partner-country comparison technique, Sheikh samples 36 different products and the partner countries that supplied over 80 percent of Pakistan's imports at the time. He then divides these commodities into two broad groups - restricted and liberal - based on a careful examination of the incidence of import licensing. The results show that, for goods in the restricted category, there is a very robust tendency for Pakistani import values to fall considerably below the partner country's export figures, representing import under-invoicing for each of the four years considered. The author also institutes a relationship between under-invoicing and the categorization of a commodity as high-tariff or low-tariff, where the former is more prone to under-invoicing.

Mahmood and Mahmood (1993) estimate the volume of import under-invoicing in Pakistan from 1981 to 1988 for a sample of partner countries that include France, Germany, Italy, the UK, the Netherlands and Japan (about 40 percent of Pakistan's total imports came from these countries at the time). They find that large-scale under-invoicing occurs in chemicals, machinery, manufactured goods and transport equipment. Moreover, the commodities that are under-invoiced have significantly high duties, from 40 percent on rubber to 450 percent on automobiles.

Mahmood (1997) examines the major determinants of import under-invoicing in Pakistan for the period 1981-88 by pooling data for 96 goods and imports from six developed countries. He tests the impact of import taxes and nontariff restrictions on imports: import taxes emerge as the most significant variable with a positive correlation with import underinvoicing, while nontariff restrictions are insignificant.

Mahmood and Azhar (2001) study export over-invoicing between Pakistan and 13 major developed trading partners over the period 1984-94. At the aggregate level, exporters over-invoiced exports to the tune of US\$2.4 billion over 10 years. Mahmood (2013) is the most recent work on reverse capital flight in Pakistan. He finds that the value of reverse capital flight from 1972 to 2013 is about $\$ 30$ billion. The paper does not, however, estimate misinvoicing by commodity and country.

In sum, the problem of trade misinvoicing prevails mostly in developing countries. Industrialized countries have largely curtailed the problem. China and India account for the largest volume of misinvoicing in Asia, while most African and Middle Eastern countries also face this issue. 


\section{Empirical Model}

This study uses two different methodologies to estimate trade misinvoicing and the loss of revenue, respectively. The c.i.f. and f.o.b. methodology estimates the extent of misinvoicing in exports and imports, using the UN Commodity Trade Statistics database. We use the Standard International Trade Classification (SITC) Revision 3 commodity codes to compare the exports of the reporting country with the imports of the partner country and vice versa.

The study incorporates 52 major traded commodities and 21 developed trading partners for the period 1972-2013 (see Tables A1 and A2 in the Appendix). ${ }^{1}$ In total, more than 45,000 trade entries were reviewed to identify the volume of trade misinvoicing. The methodology for calculating revenue loss is taken from Baker et al. (2014), who have used it to estimate revenue losses from trade misinvoicing in Africa.

What is important to mention is that the UN Comtrade dataset has missing trade values for multiple goods across various years. If we were to compute the model without adjusting the data for both the reporting and partner country, this would generate statistical discrepancies that have nothing to do with misinvoicing. For example, if Pakistan reports steel exports for 2013 but its partner country, the US, does not, then the software will identify all steel exports as over-invoiced exports from Pakistan, leading to a huge discrepancy. To handle this loophole, we have explicitly deleted all such missing values on both sides to avoid any artificial discrepancies among the 45,000 trade entries reviewed.

\subsection{C.i.f. and f.o.b. Methodology}

Trade misinvoicing can take the form of import and export underinvoicing or over-invoicing. Naturally, the stated exports from country A to country B (after incorporating the cost of insurance and shipping or c.i.f.) should be equal to the observed imports of country B from country A. Using the IMF criteria, we adjust the c.i.f. value by a factor of 1.1, which represents the cost of insurance and shipping and makes the c.i.f. equivalent to the f.o.b.

$$
M I=M I_{. X}+M I_{\cdot M}=\text { misinvoicing in total trade. }
$$

\footnotetext{
1 Pakistan's trading partners include Australia, Austria, Belgium, Canada, Denmark, France, Germany, Italy, Japan, the Netherlands, Norway, New Zealand, Portugal, the Republic of Korea, Singapore, Spain, Switzerland, Taiwan, the UK and the US.
} 
$M I_{X}=M_{. i c p}-X_{. p i c} * a d=$ misinvoicing of exports.

$M I_{X}<0$ indicates export over-invoicing in Pakistan.

$M I_{X}>0$ indicates export under-invoicing in Pakistan.

$M I_{M}=M_{. p i c}-X_{. i c p} * a d=$ misinvoicing of imports.

$M I_{M}>0$ indicates import over-invoicing in the country.

$M I_{M}<0$ indicates import under-invoicing in the country.

where $M_{. i c p}=$ imports of industrial countries from Pakistan (c.i.f.), $X_{\text {.pic }}=$ Pakistan's exports to industrial countries (f.o.b.), $M_{\text {.pic }}=$ Pakistan's imports from industrial countries (c.i.f.), $X_{. i c p}=$ exports of industrial countries to Pakistan (f.o.b.) and $a d=$ adjustment factor defined as c.i.f. - f.o.b. ratio.

\subsection{Estimating Loss of Revenue}

To estimate the loss of revenue incurred by the government in the form of potential customs tariffs and export withholding tax, the following methodology is used. The net revenue lost through import misinvoicing is:

Uim per year $\mathrm{x}$ (average tariff rate of commodity + average sales tax)/100 - Oim per year $x$ (average tariff rate of commodity + average sales $\operatorname{tax}) / 100$

The net revenue lost through export misinvoicing is:

$U x$ per year $\mathrm{x}$ withholding tax on export proceeds $/ 100-O x$ per year $\mathrm{x}$ withholding tax on export proceeds $/ 100$

where Uim = import under-invoicing, Oim = import over-invoicing, $U x=$ export under-invoicing and $O x=$ export over-invoicing.

\section{Results and Interpretation}

This section presents the results obtained for the volume of trade misinvoicing and revenue losses.

\subsection{Trade Misinvoicing}

The trade misinvoicing estimates are discussed in relation to policy. 


\subsubsection{Trade Misinvoicing, by Commodity}

Table 1 provides the estimated total trade misinvoicing divided into its two main categories. The total misinvoicing for 1972-2013 is estimated at $\$ 92.7$ billion. This substantial figure shows the extent to which trade misinvoicing has occurred over the last 41 years with developed economies alone. The figure does not take account of trade misinvoicing in relation to developing trading partners and minor traded commodities. Hence, to that extent, the reported figures are underestimated. The average annual trade misinvoicing that took place in Pakistan is about $\$ 2.25$ billion.

Table 1: Total volume of trade misinvoicing

US\$ billion

\begin{tabular}{lcccc}
\hline & \multicolumn{2}{c}{ Misinvoicing } & (1972-2013) & \multicolumn{2}{c}{ Average annual misinvoicing } \\
\cline { 2 - 5 } & Imports & Exports & Imports & Exports \\
\hline Under-invoicing & 30.20 & 18.04 & 0.73 & 0.40 \\
Over-invoicing & 15.60 & 28.90 & 0.38 & 0.70 \\
Total & 45.80 & 46.90 & 1.10 & 1.14 \\
\hline
\end{tabular}

Source: Authors' estimates.

Export misinvoicing accounts for the largest share of total trade misinvoicing. The estimates show that export misinvoicing is higher than import misinvoicing, even though fewer commodities are taken into account for export misinvoicing than for import misinvoicing. This implies that tariff evasion is not traders' foremost objective: trade misinvoicing is conducted mainly for the purposes of capital flight and reverse capital flight, to earn black market premiums and to gain export subsidies.

A primary reason for this finding is that Pakistan has curtailed its tariffs significantly in the last two decades. Ad valorem rates were reduced from a peak of 350 percent in the 1970s to 90 percent in the early 1990s and then to 56 percent in 1995. The current average tariff is 9.9 percent. Thus, high import duties are not the only incentive for importers to misinvoice. On the other hand, exporters have benefited from various export subsidies, including duty drawback schemes in the 1970s and 1980s, and still enjoy the reimbursement of sales tax and federal excise duties on imported raw material and concessional export refinancing when claiming a higher volume of exports.

Due to various economic and political factors, capital flight and reverse capital flight have always been key issues in Pakistan. Trade 
misinvoicing remains one of the main avenues for illegal capital flight. The highest share of import misinvoicing is that of under-invoicing in the sample period (Table 1). Import under-invoicing also has the highest share of total trade misinvoicing. Table 1 shows that the larger component of export misinvoicing is over-invoicing, which is almost twice as high as export under-invoicing. This implies that the most common reasons for export misinvoicing are reverse capital flight and availing export subsidies and tax credits from the government.

These export subsidies include export refinance schemes run by the State Bank of Pakistan in which exporters reporting a certain level of annual exports are provided credit at an interest rate that is 1-1.5 percent lower than the benchmark rate. Tax credits are availed by exporters in the form of the reimbursement of sales tax paid on imported raw materials used to produce finished goods in Pakistan. Since no export duty is currently applicable on exports from Pakistan, export over-invoicing has become lucrative for exporters.

Table 2 lists the commodities with the highest level of misinvoicing in each category. Electrical machinery ranks highest in the import underinvoicing category. The customs tariff on electrical machinery was, on average, 75 percent from the 1970s to the 1990s and dropped to 25 percent in the 2000s. Given the high customs duty levied on it earlier and as the second largest import in Pakistan after oil, importers find it beneficial to under-invoice electrical machinery.

Table 2: Highest misinvoicing, by commodity, 1972-2013

\begin{tabular}{lll}
\hline Type of misinvoicing & \multicolumn{1}{c}{ Commodity } & \multicolumn{1}{c}{ Value } \\
\hline Highest under-invoicing in imports & Electrical machinery & US $\$ 6.10$ billion \\
Highest over-invoicing in imports & Iron and steel & US $\$ 1.20$ billion \\
Highest under-invoicing in exports & Linen & US $\$ 2.59$ billion \\
Highest over-invoicing in exports & Undergarments & US $\$ 4.90$ billion \\
\hline
\end{tabular}

Source: Authors' estimates.

Iron and steel are found to be the most over-invoiced import in the sample period. Import over-invoicing is also used widely to lower the taxable portion of profit. For example, with a current corporate tax rate of 35 percent and assuming an import duty rate of 25 percent on a specific item, it would still make sense to pay the higher import duty through import over-invoicing because the company would then pay lower taxes owing to the higher import costs that eat into its declared profit. In 
Pakistan, as in most other developing countries, trade taxes have fallen with trade-based globalization while corporate taxes remain high because the government needs to make up the revenue shortfall through an increase in direct taxes. Under the circumstances, import over-invoicing continues to be a lucrative way of shifting profits.

Overall, linen is found to be the most under-invoiced export. The textiles sector contributes the largest share to Pakistan's exports. Exporters of linen fabric are less interested in availing export subsidies than in capital flight primarily because the linen industry, which dominates the textiles export sector, accounts for more than $\$ 3$ billion in exports annually. In availing export subsidies tied to performance requirements, linen exporters do not over-invoice their exports to avail subsidies, but under-invoice exports instead.

Apart from the direct benefits of enabling capital flight and a lower withholding tax on exports, export under-invoicing also decreases declared export revenues. This lowers declared corporate profits and, therefore, taxable profits for the company. Thus, there are two components: the exporter benefits from a lower withholding tax at the export stage and then from a lower corporate tax on gross profits. From the national economy's point of view, the capital shifted abroad through under-invoicing is greater than the taxable portion of the amount shifted. Additionally, Pakistan incurs a foreign exchange loss when its reserves are already low.

Undergarments are the most over-invoiced export. There are no hindrances to over-invoicing these exports as exporters pay a paltry 1 percent tax on export proceeds. On the contrary, the benefits gained from export subsidies or the black market premium exceed the losses incurred in paying higher export taxes.

The top ten commodities under-invoiced and over-invoiced during the sample period are shown in Figures 1-4. The percentages show the ratio of misinvoicing to total imports or exports in that commodity, while the bar chart values depict misinvoicing in absolute terms.

Figure 1 shows that electrical machinery is the highest underinvoiced import. However, as a share of total imports, automobile parts are the highest under-invoiced commodity for this period. These are imported mainly from Japan and bear an average tariff of 50 percent. Similarly, in absolute terms, vehicles are the second most under-invoiced import mainly because the average tariff on vehicles is about 175 percent. Vehicles and 
their parts remain a major source of revenue for the government in the form of a high customs tariff, which has reached up to 250 percent in the past, inducing importers to under-invoice.

Figure 1: Top ten imports under-invoiced, 1972-2013

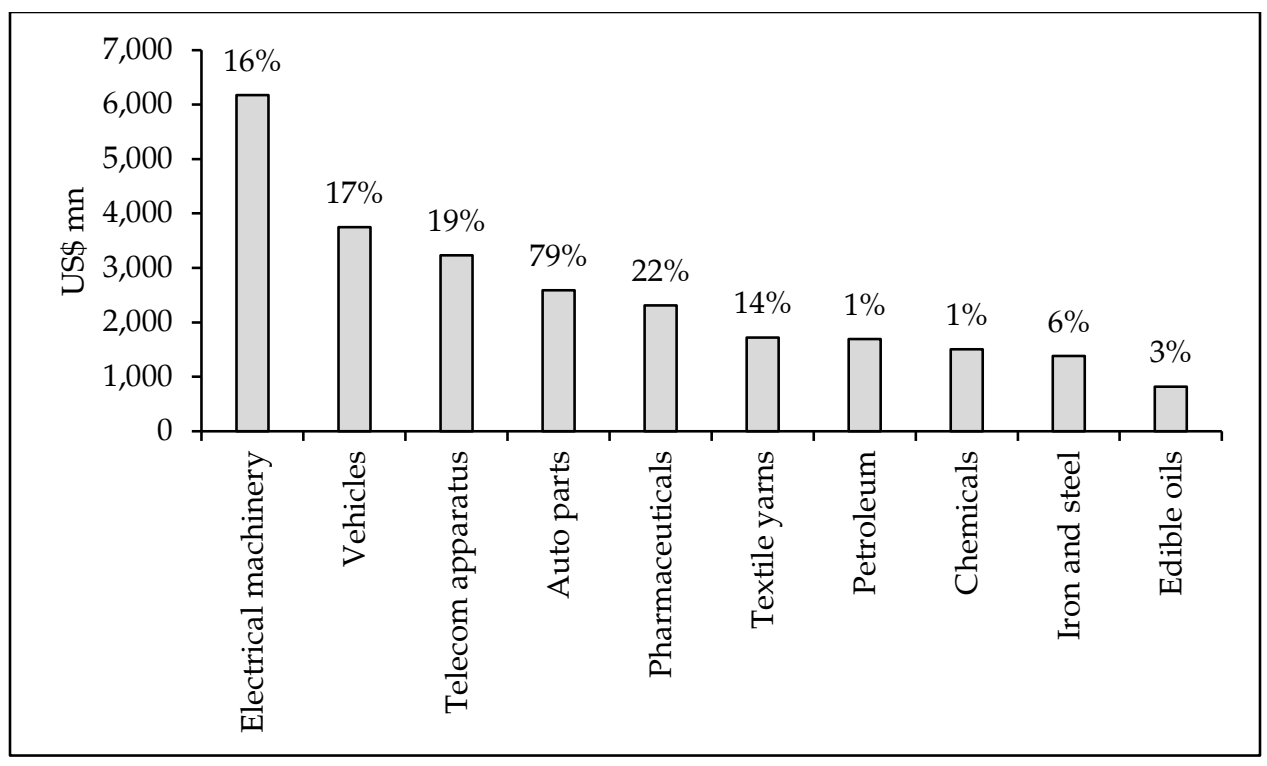

Figure 2 shows that the highest over-invoiced import as a share of total imports is motorcycles and their parts. These bear an average customs tariff of 95 percent, which makes them expensive for importers to overinvoice. Vehicles are the second most over-invoiced import in absolute terms and have very high tariff rate. These findings suggest that tariff structure is not a major deterrent to, or reason for, import over-invoicing and under-invoicing. Thus, importers under-invoice and over-invoice for other reasons such as capital flight and reverse capital flight.

Black money holders transfer their capital out of Pakistan using the services of major importers of vehicles and motorcycles in return for a service fee. Our findings show that money launderers do not mind paying high duties when over-invoicing these items because those who transfer their black money abroad pay the additional customs duties out of the black money. Such high costs are bearable so long as the aim of capital flight is achieved.

Figure 3 shows that the highest over-invoiced export as a share of total exports is bags and blankets at 450 percent over the sample period. 
This extent of over-invoicing is an outlier compared to the other estimates. The total exports of bags and blankets in 2013 were $\$ 57$ million.

Figure 2: Top ten imports over-invoiced, 1972-2013

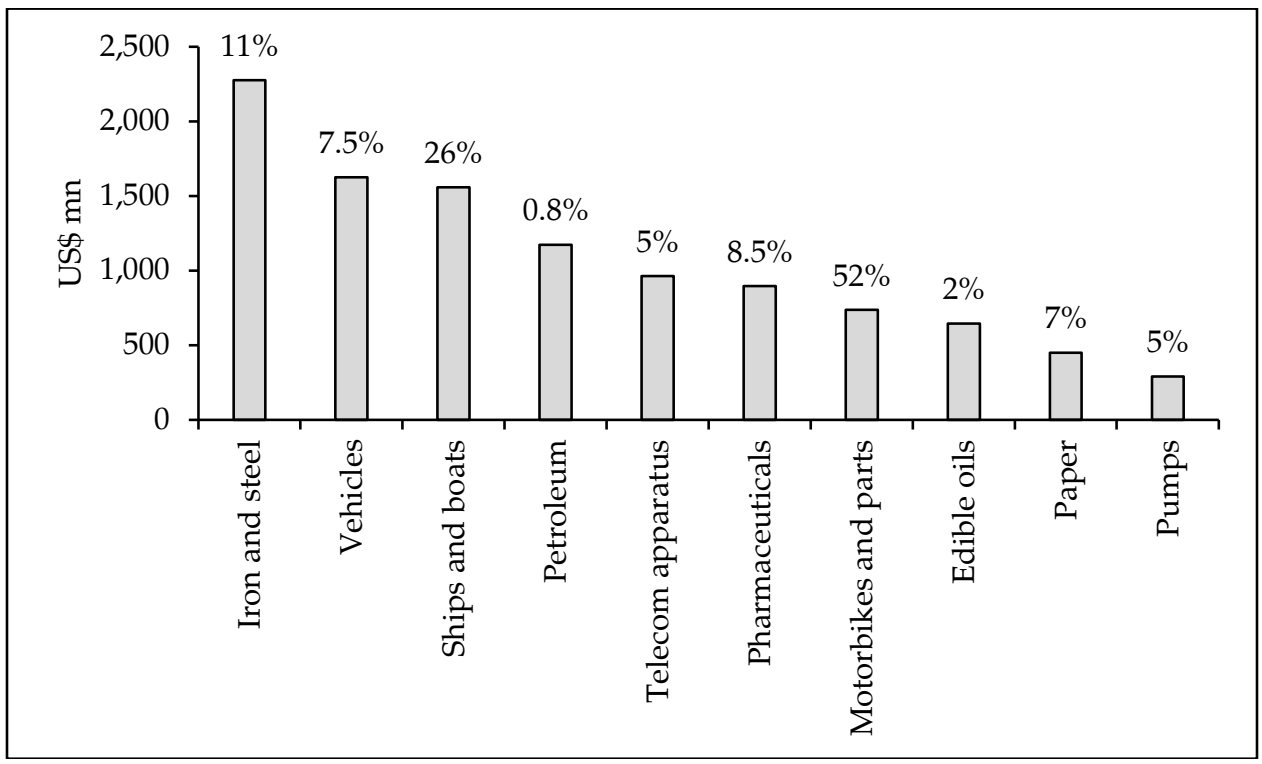

Figure 3: Top ten exports over-invoiced, 1972-2013

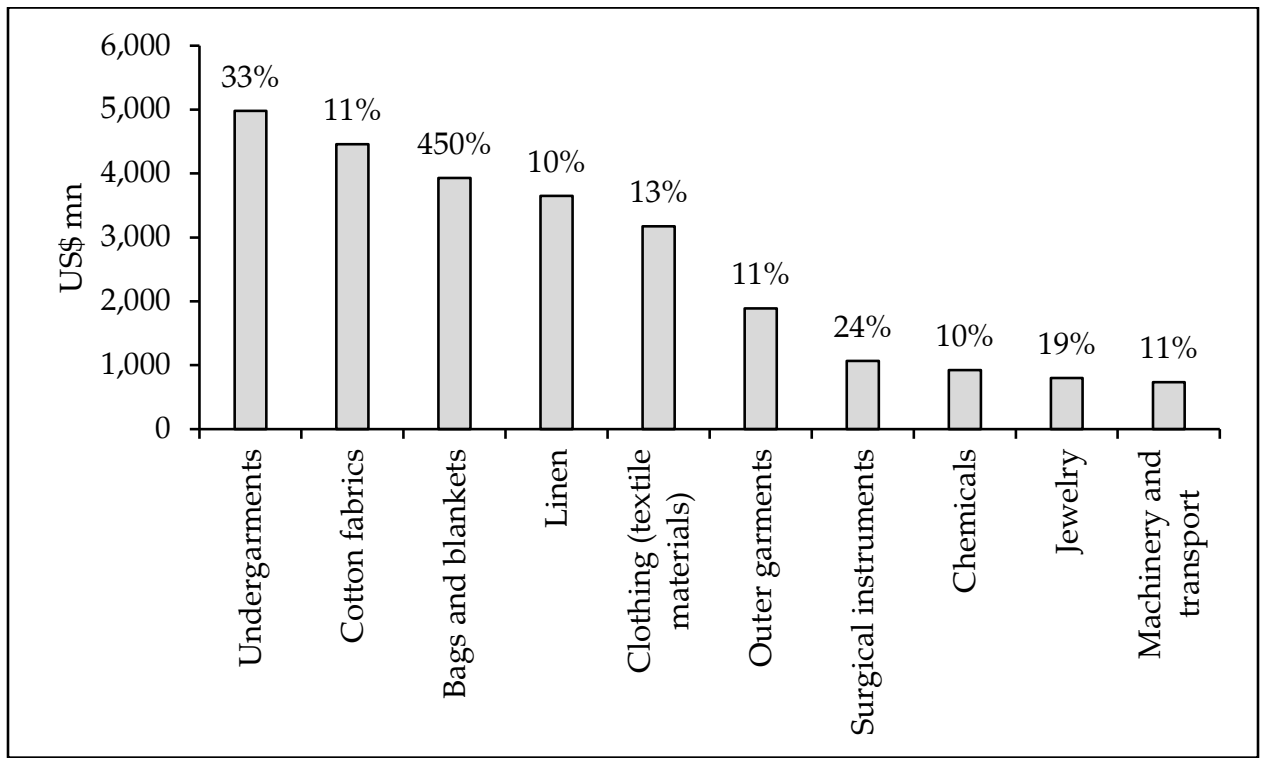


This implies that, to avail export subsidies such as export refinance schemes that are tied to performance, exporters of bags and blankets greatly over-invoice their exports. It could be argued that the industry's actual performance is worse than its reported performance and that it is the largest beneficiary of export subsidies in Pakistan. Reverse capital flight may be another reason for such high levels of export over-invoicing.

Figure 4 shows that bags and blankets are the most under-invoiced export, with 252 percent of total exports in this sector being under-invoiced during the sample period. Again, this leads to the earlier argument that the same industry is subject to both kinds of misinvoicing, as in the case of vehicle imports.

Figure 4: Top ten exports under-invoiced, 1972-2013

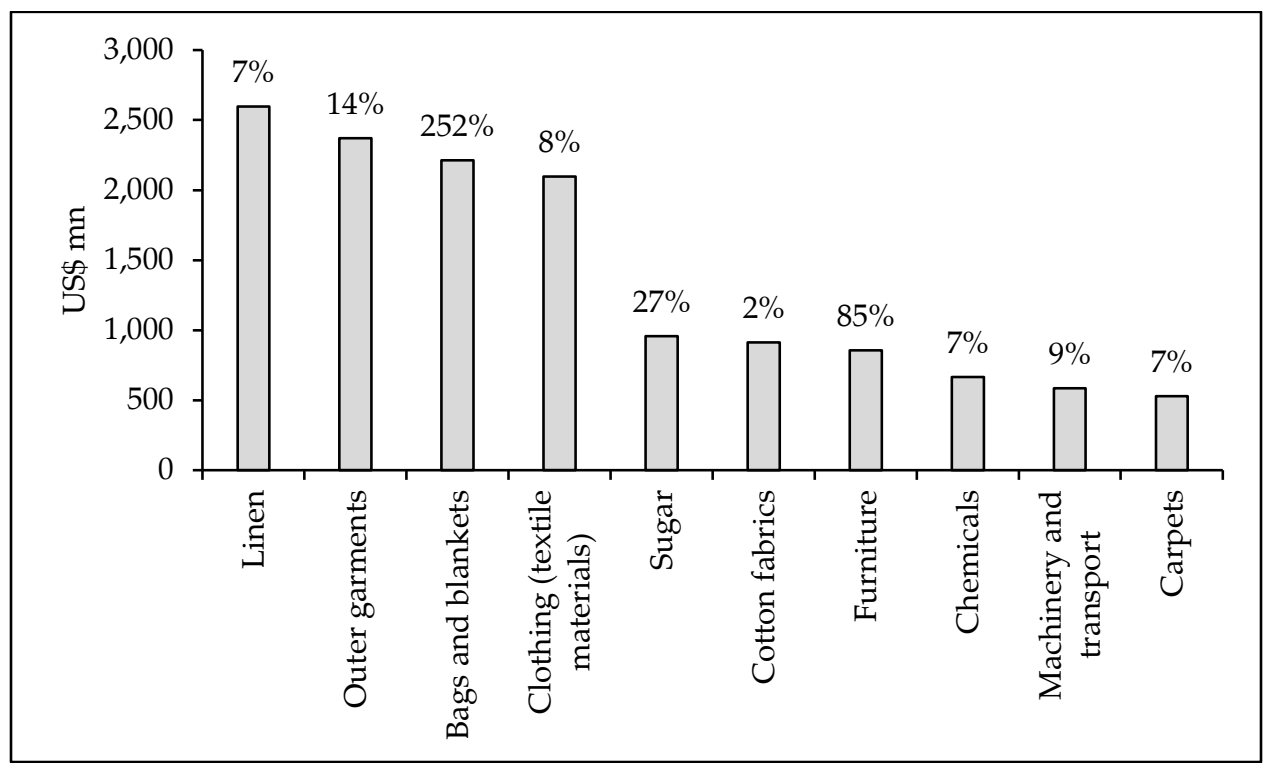

The bags and blankets industry not only enjoys export subsidies from the government through over-invoicing, but also transfers capital by severely under-invoicing its goods. Some manufacturers may be linked to those seeking to transfer their capital aboard, while others illegally avail export subsidies. The EU is the largest importer of bags and blankets from Pakistan and the analysis shows that Pakistani capital and black money holders tend to transfer their capital to Europe. 


\subsubsection{Trade Misinvoicing, by Trading Partner}

Having estimated trade misinvoicing with respect to commodity, we repeat the analysis with respect to country. For each component of trade misinvoicing, the top ten countries associated with the highest misinvoicing in terms of absolute numbers and the ratio of total imports and exports are shown in Figures 5-8.

Figure 5 shows that France is the most popular destination for overinvoiced exports as a share of total exports as well as for the illicit transfer of funds. We can argue that, once this capital reaches France, it is transferred to tax havens such as Switzerland, where banks are well known for holding billions of dollars in illicit deposits. Moreover, France and other EU countries are major importers of Pakistani linen and garments, with 27 percent of linen imports in the EU originating in Pakistan. The large extent of over-invoicing in linen and outer garments is evidence that countries such as France, the UK, Germany and Austria are major destinations for over-invoiced textile items.

Figure 5: Top ten destinations for under-invoiced exports, 1972-2013

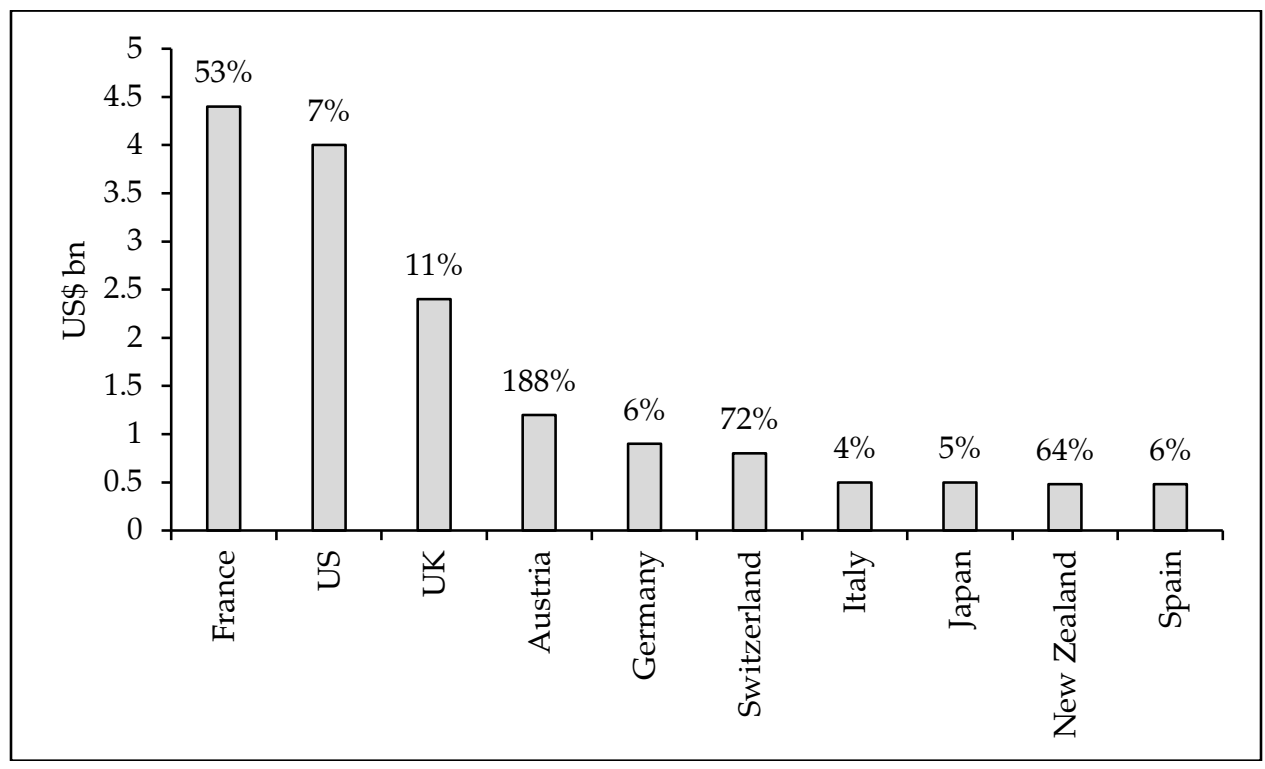

The US, on the other hand, ranks highest as a destination for underinvoiced items in absolute terms. This may be because it is a major trading partner, accounting for \$3.6 billion in exports from Pakistan in 2013. Furthermore, Pakistan exports a substantial volume of linen and outer 
garments to the US. This supports the estimate that shows outer garments and linen as being among the highest under-invoiced commodities.

Figure 6 shows the top destinations for under-invoiced exports for the sample period. Once again, the US ranks first in absolute terms. This finding echoes Mahmood (2013), who argues that people bring back their money to Pakistan when they deem that the sociopolitical environment is favorable. Thus, the large amount of capital that is transferred to the US in hard times is returned home in favorable times.

Figure 6: Top 10 destinations for over-invoiced exports, 1972-2013

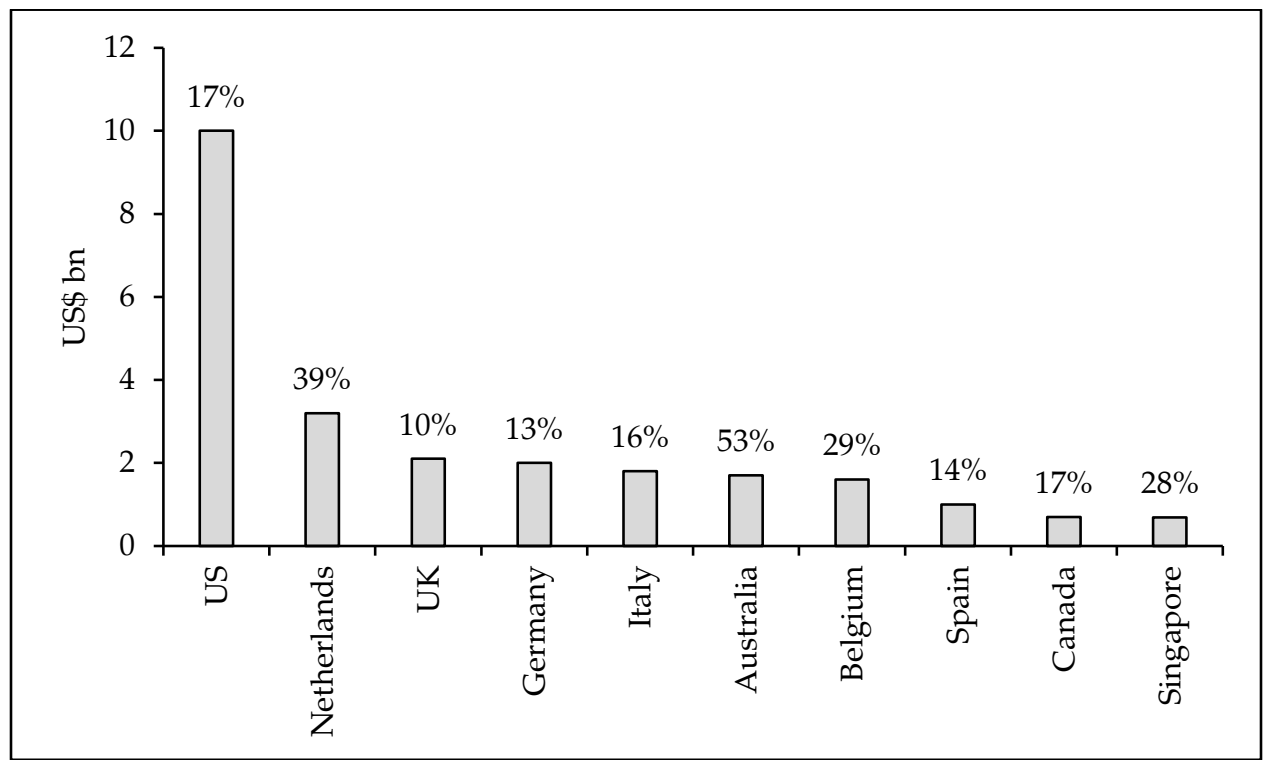

Australia is the top destination in terms of misinvoicing as a share of total exports. Pakistan's major exports to Australia are bed linen and rice. The results show that rice is Pakistan's 17th most over-invoiced export, implying that a large volume of over-invoicing occurs in its rice exports to Australia. Cotton fabrics and outer garments, which are also among the top exports to Australia, are among the most over-invoiced commodities.

Figure 7 shows the top ten destinations for under-invoiced imports. The highest import under-invoicing as well as import over-invoicing recorded is with respect to Japan. The results show that vehicles and parts and motorcycles and parts are the most under-invoiced and over-invoiced imports, respectively (Figures 7 and 8). Japan is the largest exporter of 
these goods to Pakistan, justifying its position as the top destination for misinvoicing in absolute numbers. However, Taiwan ranks first in terms of the ratio of misinvoicing to total imports at 188 percent. Textile yarn is the most under-invoiced import from Taiwan.

Figure 7: Top 10 destinations for under-invoiced imports, 1972-2013

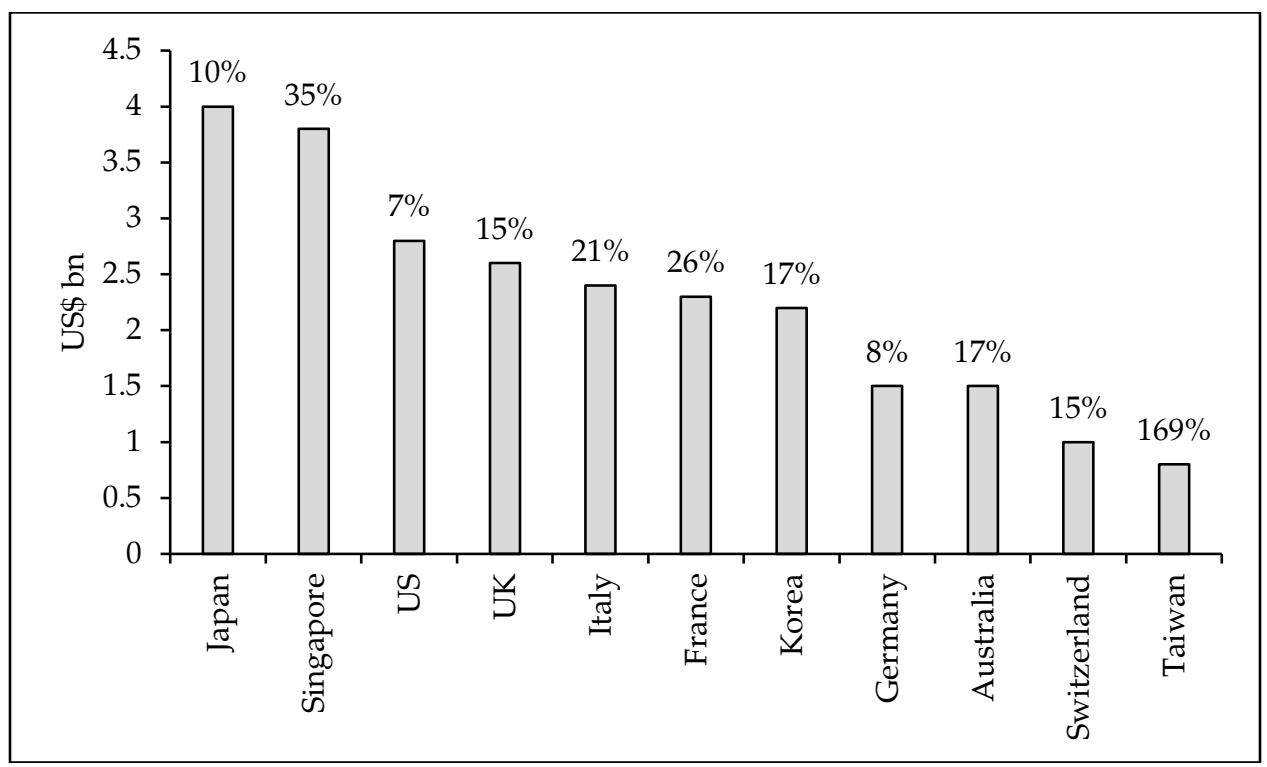

Figure 8: Top 10 destinations for over-invoiced imports, 1972-2013

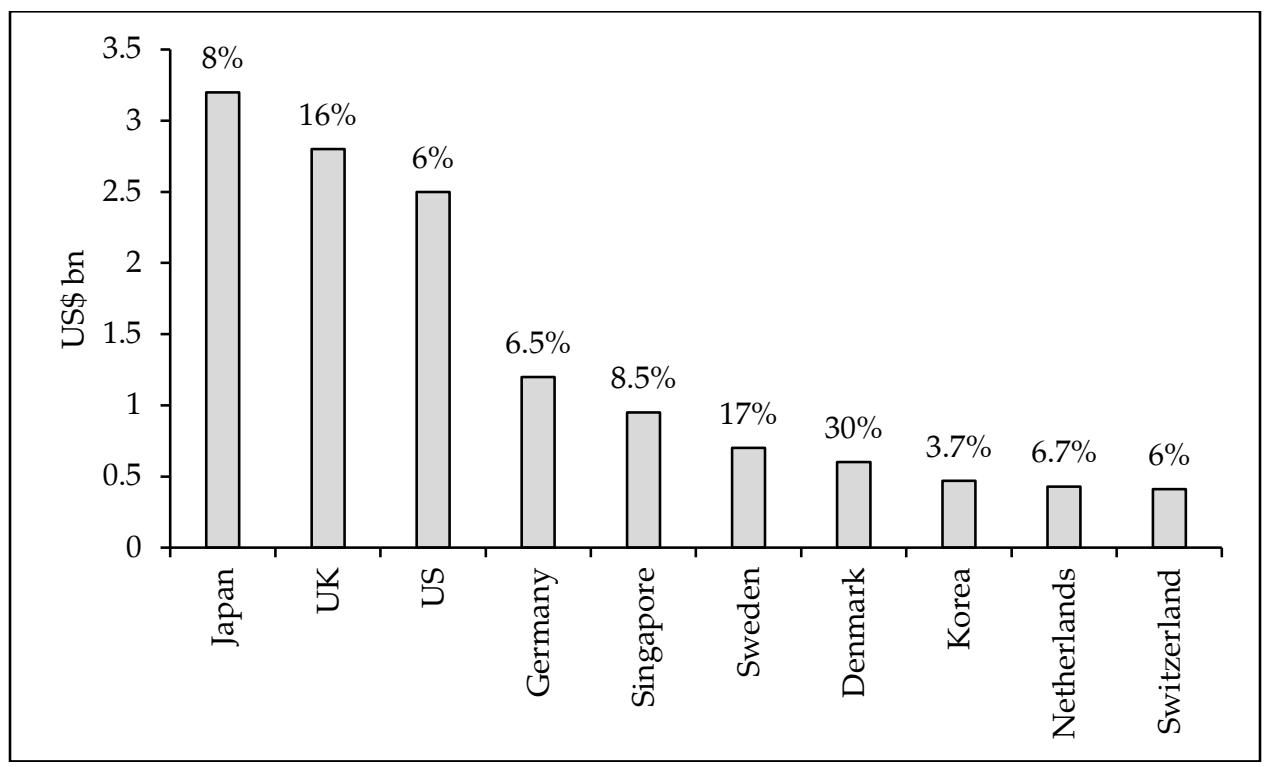




\subsection{Gross Revenue Losses}

Table 3 reports the losses incurred by the national exchequer due to import under-invoicing in the form of lost customs duties. This amounts to an estimated $\$ 21.2$ billion in revenue lost during 1972-2013 and an average annual revenue loss of $\$ 0.5$ billion. The gross revenue losses due to export under-invoicing are the potential revenues that could have been obtained from withholding tax on export proceeds had those exports not been under-invoiced. The total revenue loss is estimated at $\$ 0.18$ billion, with an annual average of $\$ 4.4$ million.

Table 3: Gross and net revenue loss, 1972-2013

US\$ billion

\begin{tabular}{lccccc}
\hline & \multicolumn{2}{c}{$\begin{array}{c}\text { Losses due to under- } \\
\text { invoicing of }\end{array}$} & \multicolumn{2}{c}{$\begin{array}{c}\text { Gains due to over- } \\
\text { invoicing of }\end{array}$} & Net revenue loss \\
\cline { 2 - 6 } & Imports (A) & Exports (B) & Imports (C) & Exports (D) & (A + B) - (C + D) \\
\hline Total & 21.2 & 0.1800 & 10.40 & 0.29 & 11.00 \\
Average & 0.5 & 0.0044 & 0.26 & 0.01 & 0.26 \\
annual & & & & & \\
\hline
\end{tabular}

Source: Authors' estimates.

\subsubsection{Gross Revenue Gains}

The sum of gross revenue gains to the national exchequer due to import over-invoicing in the form of customs duties is $\$ 10.4$ billion for the sample period, while the annual average gain is estimated at $\$ 0.26$ billion (Table 3). The revenue gains from export over-invoicing occur in the form of the 1 percent withholding tax that is received on almost all export proceeds in Pakistan. The total revenue gain accounted was $\$ 0.29$ billion in the sample period, which is very small, given the low to zero direct export taxes levied in Pakistan.

\subsubsection{Net Revenue Loss}

The net revenue loss is the sum obtained after subtracting gross revenue losses from gross revenue gains. The total net revenue loss to the national exchequer incurred in the form of potential customs duties and export withholding tax is estimated at $\$ 11$ billion (Table 3), while the average annual net revenue loss is estimated at $\$ 0.26$ billion. It is pertinent to mention here that the total tax collected by the Federal Board of Revenue through custom duties was PRs241 billion in 2013/14. The average annual net revenue loss estimated by this study is $\$ 0.26$ billion or PRs27 billion, 
which is about 11.2 percent of the total tax collected through customs duties. It is also important to note that we have estimated this loss by incorporating only Pakistan's developed trading partners. If the losses incurred through trade with developing trading partners were also incorporated, this would greatly inflate the net revenue loss.

\section{Factors Influencing Trade Misinvoicing}

Having established the prevalence of misinvoicing in Pakistan's trade sector, it is also imperative to understand which factors have, over time, deterred or induced trade misinvoicing. Taking economic theory into consideration, we generate the following four econometric models (see Table A3 in the Appendix for an explanation of variables and data sources).

The models take into account the trade conducted with the same 21 trading partners. Since this is not a commodity-specific regression analysis, the data encompasses all imports and exports for the period 1980-2013. Hence, more data is available for analysis. We apply the robust least squares method because its estimates are corrected for serial correlation and heteroskedasticity.

Model 1 is written as:

$$
\begin{aligned}
U_{x}= & \alpha+\beta_{1} \text { interest }_{t}+\beta_{2} \text { polity }_{t}+\beta_{3} C A B_{t-1}+\beta_{4} C A O_{t}+\beta_{5} T L_{t}+ \\
& \beta_{6} \text { REER }_{t}+\epsilon_{t}
\end{aligned}
$$

Model 2 is written as:

$$
\begin{aligned}
U_{\text {im }}= & \alpha+\beta_{1} \text { interest }_{t}+\beta_{2} \text { tariff }_{t}+\beta_{3} \text { polity }_{t}+\beta_{4} \text { CAB }_{t-1}+\beta_{5} C A O_{t}+ \\
& \beta_{6} T L_{t}+\beta_{7} \text { REER }_{t}+\epsilon_{t}
\end{aligned}
$$

UN Comtrade lacks data for the year 1994 for Pakistan and so, is not included in the regression. Trade data for Taiwan is available only from 1989 onwards, for Germany from 1991 onwards and for Belgium from 1999 and onwards.

Model 3 is written as:

$$
\begin{aligned}
O_{x}= & \alpha+\beta_{1} \text { interest }_{t}+\beta_{2} \text { polity }_{t}+\beta_{3} C A B_{t-1}+\beta_{4} C A O_{t}+\beta_{5} T L_{t}+ \\
& \beta_{6} \text { REER }_{t}+\epsilon_{t}
\end{aligned}
$$


Model 4 is written as:

$$
\begin{aligned}
O_{\text {im }}= & \alpha+\beta_{1} \text { interest }_{t}+\beta_{2} \text { tariff }_{t}+\beta_{3} \text { polity }_{t}+\beta_{4} C A B_{t-1}+\beta_{5} C A O_{t}+ \\
& \beta_{6} T L_{t}+\beta_{7} \text { REER }_{t}+\epsilon_{t}
\end{aligned}
$$

All the variables are taken in period $t$ except for the current account balance $(\mathrm{CAB})$, the lagged value of which is added as a regressor. The $\mathrm{CAB}$ suffers from the problem of endogeneity in the form of reverse causality. Although it is a determinant of misinvoicing, a large enough figure for over-invoiced exports will inflate the $\mathrm{CAB}$ while a high value for import over-invoicing will enhance the current account deficit. To deal with the issue of reverse causality, we take the lagged value of the $C A B-C A B(-1)-$ as an explanatory variable because trade misinvoicing in period $t$ cannot inflate or deflate the $\mathrm{CAB}$ in period $t-1$ However, the $\mathrm{CAB}$ in period $t-1$ can affect the extent of misinvoicing in period $t$.

The first and third models do not include the tariff rate because it bears no direct relation to exports. In the model for export under-invoicing, the two main aims of the agent are assumed to be either flight of capital or to pay less withholding tax and corporate tax liable on the profits of the company (by under-invoicing exports, the value of total revenue and net profit declines). Table 4 gives the results for all four models.

\begin{tabular}{|c|c|c|c|c|}
\hline \multirow[b]{2}{*}{$\begin{array}{l}\text { Independent } \\
\text { variables }\end{array}$} & \multicolumn{4}{|c|}{ Dependent variables (in US\$ mn) } \\
\hline & $\begin{array}{c}\text { Under-invoicing } \\
\text { of exports }\end{array}$ & $\begin{array}{l}\text { Over-invoicing } \\
\text { of imports }\end{array}$ & $\begin{array}{c}\text { Over-invoicing } \\
\text { of exports }\end{array}$ & $\begin{array}{c}\text { Under-invoicing } \\
\text { of imports }\end{array}$ \\
\hline Tariff & - & $\begin{array}{l}-8.29 \\
(-2.32)^{* * *}\end{array}$ & - & $\begin{array}{l}69.34 \\
(5.54)^{* * *}\end{array}$ \\
\hline Interest & $\begin{array}{c}0.84 \\
(0.83)\end{array}$ & $\begin{array}{l}16.72 \\
(1.75)^{*}\end{array}$ & $\begin{array}{r}-25.50 \\
(1.59)\end{array}$ & $\begin{array}{l}126.67 \\
(3.80)^{* * *}\end{array}$ \\
\hline Polity & $\begin{array}{l}-0.54 \\
(-0.20)\end{array}$ & $\begin{array}{l}-13.60 \\
(-3.20)^{* * *}\end{array}$ & $\begin{array}{c}1.54 \\
(0.22)\end{array}$ & $\begin{array}{l}-24.96 \\
(-1.71)^{*}\end{array}$ \\
\hline CAB $(-1)$ & $\begin{array}{l}15.04 \\
(2.66)^{* * *}\end{array}$ & $\begin{array}{l}-26.89 \\
(-3.08)^{* * * *}\end{array}$ & $\begin{array}{l}-18.76 \\
(-1.27)\end{array}$ & $\begin{array}{l}34.96 \\
(1.14)\end{array}$ \\
\hline $\mathrm{CAO}$ & $\begin{array}{l}12.89 \\
(0.11)\end{array}$ & $\begin{array}{r}-126.50 \\
(-0.73)\end{array}$ & $\begin{array}{l}13.85 \\
(0.04)\end{array}$ & $\begin{array}{r}462.43 \\
(0.70)\end{array}$ \\
\hline TL & $\begin{array}{c}6.74 \\
(1.30)\end{array}$ & $\begin{array}{l}15.50 \\
(2.11)^{* *}\end{array}$ & $\begin{array}{l}-28.00 \\
(-2.20)^{* *}\end{array}$ & $\begin{array}{l}-47.14 \\
(1.83)^{*}\end{array}$ \\
\hline REER & $\begin{array}{l}-0.30 \\
(-0.81)\end{array}$ & $\begin{array}{c}0.48 \\
(0.30)\end{array}$ & $\begin{array}{l}2.70 \\
(2.48)^{* * *}\end{array}$ & $\begin{array}{l}-17.69 \\
(-3.57)^{* * *}\end{array}$ \\
\hline
\end{tabular}

Table 4: Robust least squares estimates

Note: $z$-stats in parentheses. ${ }^{*}=$ significant at $10 \%,{ }^{* *}=$ significant at $5 \%,{ }^{* * *}=$ significant at $1 \%$. Source: Authors' estimates. 
In the case of import over-invoicing, agents' primary aim is to enable capital flight or claim higher-than-actual duty drawbacks. Exports are over-invoiced to retrieve capital from abroad or to claim higher benefits from export finance schemes. Finally, import under-invoicing occurs mainly to pay smaller customs tariffs on imports and is also a tool enabling reverse capital flight.

The tariff rate variable is highly significant and positively associated with import under-invoicing. As shown in Table 4, a 1 percent increase in the tariff increases import under-invoicing by $\$ 69$ million on average. This result bolsters the argument that higher customs duties are the primary reason for import under-invoicing. This result is in line with Mahmood (1997) and Patnaik, Gupta and Shah (2010), who also find the tariff rate to be highly and positively associated with import underinvoicing in Pakistan and other developing countries.

The coefficient of import over-invoicing is negative and significant, suggesting that a 1 percent increase in the customs tariff decreases import over-invoicing by $\$ 8.29$ million on average. This shows that customs tariffs can deter agents from sending their capital abroad. Agents will pay the higher duty so long as the benefit accruing from capital flight outweighs the associated cost (Bhagwati, 1973).

The interest rate is insignificant with respect to exports, showing that exporters are less concerned about the domestic interest rate even though Pakistan has sustained higher interest rates than the international market, averaging 10.7 percent over the last three decades. The interest rate has a positive and significant coefficient with respect to import overinvoicing and under-invoicing. The positive sign associated with import under-invoicing suggests that, when the domestic interest rate increases, agents retrieve their capital from abroad and deposit it in the domestic economy for higher gains. The positive sign associated with import overinvoicing suggests that a higher interest rate is a sign of high inflation, which leads to the depreciation of the local currency. In fear of expected depreciation, agents may opt to send their capital abroad, losing the opportunity to earn higher returns on their capital in Pakistan.

The coefficient of political stability is significant and negative with respect to import over-invoicing and under-invoicing. This suggests that import misinvoicing falls in periods of political stability. The proxy for political stability used in this model is the existence of a democratic regime in the country. We can argue that, under a democratic government, 
customs laws are strictly enforced, leading to a decline in import misinvoicing. The negative sign of the import over-invoicing variable reflects Mahmood (2013) and Jha and Nguyen (2014), who argue that political instability causes capital flight.

The lagged $C A B$ is significant with respect to export underinvoicing and import over-invoicing. An increase in the $\mathrm{CAB}$ of 1 percent of GDP in the previous year leads import over-invoicing to fall by $\$ 26$ million in the current year. Improvements in the current account reduce the flight of capital as expectations of currency devaluation fade with the rising $\mathrm{CAB}$.

A key finding is that capital account openness (CAO) is insignificant in all four models. This does not, however, imply that the capital account balance has no influence in the model. This result is very important as it rejects the intuition that, in a large and open financial sector, agents have the choice of moving their capital through the financial market (see Patnaik et al., 2010; Mahmood, 2013; Berger \& Nitsch, 2012). In the case of Pakistan, our results suggest that agents may feel that capital flight is more easily managed through misinvoicing than through the financial market. This may be because regulatory authorities such as the Securities and Exchange Commission of Pakistan conduct checks and balances or because the country's financial sector is not as open as that of other developing countries such as China, India or Turkey.

The literature has two theories as to what happens to misinvoicing when trade is liberalized. Either misinvoicing will increase because a larger tradeable sector offers more opportunities for misinvoicing or it will decrease due to trade-friendly government policies (Kar, 2010). In the case of Pakistan, our results show that both have occurred over time. Trade liberalization is significant and negative in the models for export overinvoicing and import under-invoicing. The government has continued to liberalize the trade sector in Pakistan: tariffs and para-tariffs have fallen significantly over time, quotas are now almost nonexistent and exportoriented policies have been adopted (Mahmood, 2013). As a result, import under-invoicing and export over-invoicing have witnessed a significant decline under liberal trade regimes. The coefficient of import overinvoicing is positively and significantly associated with trade liberalization. This result supports the first notion that a large importable sector, once liberalized, increases opportunities for import over-invoicing. 
The real effective exchange rate (REER) is a measure of currency overvaluation or undervaluation. With an increase in REER, an overvalued exchange rate creates expectations of currency devaluation and should induce capital flight. However, the coefficient on REER is insignificant for export under-invoicing and import over-invoicing. In our model of import under-invoicing, the negative and significant sign (less returning capital) can be interpreted to mean that, with a high REER, imports become cheaper for local consumers as their purchasing power is increased. This increases the demand for imports. The corresponding larger volume of imports is linearly associated with higher under-invoicing.

Similarly, the significant and positive sign of export over-invoicing can be explained thus: a higher REER causes the currency to be overvalued and decreases the volume of exports. This leads to a decline in chances to avail export subsidies (the main incentive for over-invoicing exports), which are tied to reported total exports. Therefore, exporters will overinvoice their exports under a high REER so that they can continue to avail export subsidies from the government.

\section{Conclusion and Policy Implications}

This study shows that Pakistan's trade sector is prone to a high level of misreporting. At the same time, the government incurs large losses in terms of potential customs duties and withholding tax on exports. Trade misinvoicing is not only a major source of capital flight and reverse capital flight, but it also deprives the national exchequer of an amount equal to 11 percent of the total revenue generated through customs duties and export tax. Consequently, trade policies devised in the presence of misinvoicing are bound to be less potent. To make trade policies effective and for the $\mathrm{CAB}$ to reflect the true picture, it is imperative that trade misinvoicing be reduced.

To this end, we recommend the following policy measures:

- Discourage export over-invoicing by devising a policy under which all exporters are awarded concessional credit without any discrimination.

- Pakistani customs should require the submission of a verified invoice from the customs of the partner country.

- High tariffs and NTBs encourage misreporting. Therefore, a policy of meaningful trade liberalization needs to be pursued. 
- Export rebates should be granted only to achieve export performance targets in nontraditional products. They should not be given under threat or pressure from the industry.

- Introduce proper scrutiny of products subject to the reimbursement of general sales tax and federal excise duty with an updated inputoutput coefficients system.

- Take punitive action against leading misinvoicers and scrutinize top exports and imports such as linen and undergarments. Scrutinize and enforce strict monitoring for all goods exported to or imported from countries identified as major sources of misinvoicing. 


\section{References}

Baker, R., Clough, C., Kar, D., LeBlanc, B., \& Simmons, J. (2014). Hiding in plain sight: Trade misinvoicing and the impact of revenue loss in Ghana, Kenya, Mozambique, Tanzania and Uganda: 2002-2011. Washington, DC: Global Financial Integrity.

Berger, H., \& Nitsch, V. (2012). 'Gotcha'! A profile of smuggling in international trade. In C. C. Storti \& P. De Grauwe (Eds.), Illicit trade and the global economy (chap. 4). Cambridge, MA: MIT Press.

Bhagwati, J. (1964). On the under-invoicing of imports. Oxford Bulletin of Economics and Statistics, 27(4), 389-397.

Bhagwati, J., \& Hansen, B. (1973). A theoretical analysis of smuggling. Quarterly Journal of Economics, 87(2), 172-187.

Centre for Systemic Peace. (2016). The polity project. Available from http://www.systemicpeace.org/polityproject.html

Chinn, M. D., \& Ito, H. (2006). What matters for financial development? Capital controls, institutions and interactions. Journal of Development Economics, 81(1), 163-192.

de Boyrie, M. E., Nelson, J. A., \& Pak, S. J. (2007). Capital movement through trade misinvoicing: The case of Africa. Journal of Financial Crime, 14(4), 474-489.

Fisman, R., \& Wei, S.-J. (2007). The smuggling of art, and the art of smuggling: Uncovering the illicit trade in cultural property and antiques (Working Paper No. 13446). Cambridge, MA: National Bureau of Economic Research.

Jha, R., \& Nguyen, T. (2014). Trade misinvoicing and macroeconomic outcomes in India (Working Paper No. 31). Canberra: Centre for Applied Macroeconomics Analysis.

Kar, D. (2010). The drivers and dynamics of illicit financial flows from India: 1948-2008. Washington, DC: Global Financial Integrity.

Kar, D., \& Spanjers, J. (2015). Illicit financial flows from developing countries: 2004-2013. Washington, DC: Global Financial Integrity. 
Mahmood, Z. (1997). Research note: Determinants of under-invoicing of imports in Pakistan. Journal of International Development, 9(1), 85-96.

Mahmood, Z. (2013). Reverse capital flight to Pakistan: Analysis of evidence. Pakistan Development Review, 52(1), 1-15.

Mahmood, Z., \& Azhar, M. (2001). On over-invoicing of exports in Pakistan. Pakistan Development Review, 40(3), 173-185.

Mahmood, Z., \& Mahmood, R. (1993). Under-invoicing of imports: A case study of Pakistan. Pakistan Developmental Review, 32(4), 1141-1155.

Ndikumana, L., \& Boyce, J. K. (2008). New estimates of capital flight from sub-Saharan African countries: Linkages with external borrowing and policy options (Working Paper No. 166). Amherst, MA: Political Economy Research Institute.

Patnaik, I., Gupta, A. S., \& Shah, A. (2010). Determinants of trade misinvoicing (Working Paper No. 2010-75). New Delhi: National Institute of Public Finance and Policy.

Sheikh, M. A (1974). Smuggling, production and welfare. Journal of International Economics, 4(4), 355-364.

United Nations Statistics Division. (2014). United Nations commodity trade statistics database. Available at http://comtrade.un.org/data/

Yalta, A. Y., \& Demir, I. (2010). The extent of trade misinvoicing in Turkey: Did post-1990 policies matter? Journal of Economic Cooperation and Development, 31(3), 41-66. 
Appendix

Table A1: List of commodities used to estimate import misinvoicing and average tariffs (percentage)

\begin{tabular}{|c|c|c|}
\hline SITC Rev 3 code & Commodity description & Average tariff \\
\hline 112 & Alcoholic beverages & 100 \\
\hline 111 & Non-alcoholic beverages & 30 \\
\hline 512 & Chemicals & 30 \\
\hline 02 & Dairy and eggs & 45 \\
\hline 411 & Animal fats and oils & 20 \\
\hline 95 & Firearms and ammunition & 60 \\
\hline 7328 & Auto parts & 50 \\
\hline 72 & Electrical machinery & 30 \\
\hline 7118 & Engines & 25 \\
\hline 7329 & Motorbikes and parts & 95 \\
\hline 7192 & Pumps & 35 \\
\hline 735 & Ships and boats & 25 \\
\hline 724 & Telecom apparatus & 50 \\
\hline 732 & Vehicles & 175 \\
\hline 684 & Aluminum & 50 \\
\hline 682 & Copper & 35 \\
\hline 67 & Iron and steel & 50 \\
\hline 664 & Glass & 40 \\
\hline 621 & Materials of rubber & 25 \\
\hline 641 & Paper & 60 \\
\hline 65 & Textile yarns, fabric and thread & 50 \\
\hline 6291 & Tyres & 40 \\
\hline 84 & Clothing & 75 \\
\hline 82 & Furniture & 75 \\
\hline 864 & Watches and clocks & 50 \\
\hline 33 & Petroleum products & 40 \\
\hline 54 & Pharmaceuticals goods & 25 \\
\hline 12 & Tobacco & 100 \\
\hline
\end{tabular}

Note: A 15 percent sales tax was added to all the commodities for all periods to calculate the loss or gain. Edible oils are not incorporated in the revenue loss methodology because the tariff on edible oils is specific and not ad valorem. Hence, an average tariff based on the invoices of goods cannot be estimated. 
Table A2: List of commodities used to estimate export misinvoicing

\begin{tabular}{ll}
\hline SITC Rev 3 code & \multicolumn{1}{c}{ Commodity description } \\
\hline 1 & Beverages \\
5 & Chemicals \\
8411 & Clothing of textile materials \\
84144 & Outer-garments \\
84143 & Undergarments \\
03 & Fish \\
05 & Fruits and vegetables \\
01 & Rice \\
075 & Spices \\
06 & Sugar \\
85 & Footwear \\
82 & Furniture \\
897 & Jewelry \\
611 & Leather \\
7 & Machinery and transport \\
54 & Pharmaceutical goods \\
2631 & Raw cotton \\
8944 & Sports goods \\
8617 & Surgical goods \\
656 & Bags and blankets \\
657 & Carpets and rugs \\
652 & Cotton fabric \\
6537 & Knitted fabrics \\
65691 & Linen \\
\hline
\end{tabular}




\section{Table A3: Data sources and justification of variables}

\begin{tabular}{|c|c|c|}
\hline Variable & Justification & Source \\
\hline $\begin{array}{l}\text { Import and export } \\
\text { misinvoicing }\end{array}$ & $\begin{array}{l}\text { C.i.f. and f.o.b. values used to } \\
\text { estimate the difference } \\
\text { between reported trade by the } \\
\text { partner and the reporting } \\
\text { country. }\end{array}$ & UN Comtrade \\
\hline $\begin{array}{l}\text { Trade liberalization } \\
\text { (TL) }\end{array}$ & $\begin{array}{l}\text { A larger tradeable sector offers } \\
\text { greater opportunities for } \\
\text { agents to misinvoice imports } \\
\text { and exports with the aim of } \\
\text { moving capital outside the } \\
\text { country. } \\
\text { Imports + exports/GDP * } 100\end{array}$ & World Development Indicators \\
\hline $\begin{array}{l}\text { Current account } \\
\text { balance }(\% \text { of GDP) } \\
(\mathrm{CAB})\end{array}$ & $\begin{array}{l}\text { A larger current account deficit } \\
\text { increases the chances of local } \\
\text { currency devaluation and } \\
\text { reduces the incentive to invest } \\
\text { in local assets, encouraging } \\
\text { investors to acquire assets } \\
\text { abroad. }\end{array}$ & State Bank of Pakistan \\
\hline $\begin{array}{l}\text { Political stability } \\
\text { (polity) }\end{array}$ & $\begin{array}{l}\text { High political instability } \\
\text { implies that investors prefer to } \\
\text { move their capital out of the } \\
\text { country, as the government } \\
\text { may implement actions that } \\
\text { decrease the value of their } \\
\text { holdings. }\end{array}$ & $\begin{array}{l}\text { Polity IV dataset. } \\
\text { The variable is obtained by } \\
\text { taking the difference between } \\
\text { the democracy and } \\
\text { dictatorship indices. The } \\
\text { democratic and politically } \\
\text { stable characteristics of a } \\
\text { country }=10 \text { points and the } \\
\text { authoritarian and less stable } \\
\text { characteristics }=-10 \text {. }\end{array}$ \\
\hline Interest rate & $\begin{array}{l}\text { A lower domestic interest rate } \\
\text { and higher international } \\
\text { interest rate induces flight of } \\
\text { capital, as investors seek to } \\
\text { invest where the interest rate is } \\
\text { higher. }\end{array}$ & State Bank of Pakistan \\
\hline Customs tariff & $\begin{array}{l}\text { Agents seek to under-invoice } \\
\text { imports to pay lower customs } \\
\text { duties. }\end{array}$ & $\begin{array}{l}\text { Average aggregated annual } \\
\text { customs tariff } \\
\text { Federal Board of Revenue } \\
\text { Annual reviews, Government } \\
\text { of Pakistan }\end{array}$ \\
\hline $\begin{array}{l}\text { Real effective } \\
\text { exchange rate (REER) }\end{array}$ & $\begin{array}{l}\text { Ratio of domestic to } \\
\text { international prices. An } \\
\text { overvalued exchange rate } \\
\text { creates expectations of } \\
\text { currency devaluation and } \\
\text { induces capital flight. }\end{array}$ & World Development Indicators \\
\hline
\end{tabular}




\begin{tabular}{lll}
\hline Variable & \multicolumn{1}{c}{ Justification } & \multicolumn{1}{c}{ Source } \\
\hline Capital account & When countries liberalize their & Dataset obtained from Chinn \\
openness (CAO) & financial markets, local & $\begin{array}{l}\text { and Ito (2006). The Chinn-Ito } \\
\text { investors can invest in foreign } \\
\text { index ranges from }-2.54 \text { to }\end{array}$ \\
& $\begin{array}{ll}\text { assets legally. The incentive to } \\
\text { move capital outside illegally, } \\
\text { therefore, diminishes. }\end{array}$ & $\begin{array}{l}2.54 \text {, where higher values } \\
\text { indicate greater financial } \\
\text { openness. }\end{array}$ \\
\hline
\end{tabular}

